THE EFFECT OF FINANCIAL PERFORMANCE AND GOOD CORPORATE GOVERNANCE ON STOCK RETURNS WITH PRICE BOOK VALUE AS A MODERATING VARIABLE IN BANKING COMPANIES ON THE INDONESIAN STOCK EXCHANGE

\title{
PENGARUH KINERJA KEUANGAN DAN GOOD CORPORATE GOVERNANCE TERHADAP RETURN SAHAM DENGAN PRICE BOOK VALUE SEBAGAI VARIABEL MODERASI PADA PERUSAHAAN PERBANKAN DI BURSA EFEK INDONESIA
}

\author{
Oleh: \\ Iin Tamarisa ${ }^{1)}$ Mukhzarudfa $^{2)}$ Wiralestari $^{3)}$ \\ ${ }^{1)}$ Alumni Magister Ilmu Akuntansi Pascasarjana Universitas Jambi Tahun 2021 bekerja di Balai Wilayah Sungai \\ Sumatera VI Kementerian PUPR Jambi - Indonesia \\ ${ }^{2 \& 3)}$ Fakultas Ekonomi dan Bisnis Universitas Jambi - Indonesia
}

Email: $\underline{\text { iin.tamarisa@gmail.com }}{ }^{1)}$ mukhzarudfa@unja.ac.id, ${ }^{2}{ }^{2}$ wiralestari11@unja.ac.id ${ }^{3)}$

\begin{abstract}
This study aims to analyze the effect of return on assets (ROA), debt to equity ratio (DER), non-performing loans $(N P L)$, good corporate governance (GCG) on stock returns moderated by price book value (PBV). The population of this study are banking companies listed on the Indonesia Stock Exchange (IDX) for the 2015-2019 period. This sample selection used purposive sampling method. Hypothesis testing using multiple linear regression analysis and Moderated Regression Analysis (MRA) with statistical procedures using SPSS software version 25. The results showed that return on assets (ROA), debt to equity ratio (DER), non-performing loans (NPL), good corporate governance (GCG) had an effect on stock returns. Based on the results of the MRA interaction test, price book value $(P B V)$ can moderate the effect of return on assets (ROA), debt to equity ratio (DER), non-performing loans $(N P L)$, good corporate governance (GCG).
\end{abstract}

Keywords: Return On Assets (ROA), Debt To Equity Ratio (DER), Non Performing Loan (NPL), Good Corporate Governance (GCG), Price Book Value, Stock Return

\begin{abstract}
ABSTRAK
Penelitian ini bertujuan untuk menganalisis pengaruh return on assets (ROA), debt to equity ratio (DER), non performing loan (NPL), good corporate governance (GCG) terhadap return saham dimoderasi oleh price book value (PBV). Populasi dari penelitian ini adalah perusahaan perbankan yang terdaftar di Bursa Efek Indonesia (BEI) periode 2015-2019. Pemilihan sampel ini menggunakan metode purposive sampling. Pengujian hipotesis menggunakan analisis regresi linear berganda dan Moderated Regression Analysis (MRA) dengan prosedur statistik menggunakan software SPSS versi 25. Hasil penelitian menunjukkan return on assets (ROA), debt to equity ratio (DER), non performing loan (NPL), good corporate governance (GCG) berpengaruh terhadap return saham. Berdasarkan hasil uji interaksi MRA, price book value (PBV) dapat memoderasi pengaruh return on assets (ROA), debt to equity ratio (DER), non performing loan (NPL), good corporate governance (GCG).

Kata kunci: Return On Assets (ROA), Debt To Equity Ratio (DER), Non Performing Loan (NPL), Good Corporate Governance (GCG), Price Book Value, Return Saham
\end{abstract}




\section{PENDAHULUAN}

\subsection{Latar Belakang}

Return adalah motivasi utama investor dalam berinvestasi. Investor yang telah rela menanamkan sebagian kekayaannya untuk diinvestasikan mengharapkan return sebagai hal yang paling utama. Menurut Jogiyanto (2014), return saham merupakan kelebihan harga jual saham di atas harga belinya. Semakin tinggi harga jual saham di atas harga belinya, maka semakin tinggi pula return yang diperoleh investor.

Cara paling dasar dan termudah untuk mengukur nilai saham adalah dengan melihat nilai pasar perusahaan. Ini juga dikenal sebagai kapitalisasi pasar perusahaan. Kapitalisasi pasar adalah nilai yang diperoleh ketika semua saham beredar dari saham perusahaan dikalikan dengan harga saat ini dari satu saham (Mohammed, 2017). Perkembangan perdagangan saham sektoral tahun 2019 pada perusahaan yang terdaftar di Bursa Efek Indonesia yang dipublikasikan oleh Otoritas Jasa Keuangan (OJK) menunjukkan bahwa sektor yang paling dominan adalah pada sektor keuangan, industri konsumsi, infrastruktur dan perdagangan dari seluruh kapitalisasi pasar di Bursa Efek Indonesia pada tahun 2019 maupun pada tahuntahun sebelumnya (OJK, 2019).

Investor yang akan berinvestasi di pasar modal terlebih dahulu melihat saham perusahaan yang paling menguntungkan, dengan menilai kinerja perusahaan yang bersangkutan. Kinerja keuangan adalah usaha formal yang telah dilakukan oleh perusahaan yang dapat mengukur keberhasilan perusahaan dalam menghasilkan laba, sehingga dapat melihat prospek, pertumbuhan, dan potensi perkembangan baik perusahaan dengan mengandalkan sumber daya yang ada. Suatu perusahaan dapat dikatakan berhasil apabila telah mencapai standar dan tujuan yang telah ditetapkan (Brigham \& Houston, 2017).

Sektor perbankan merupakan industri yang paling banyak diatur oleh pemerintah mengingat kepentingannya sektor ini dalam perekonomian negara sebagai sumber pembiayaan sektor riil. Saham industri perbankan merupakan salah satu saham yang sangat diminati oleh para investor (Perdana \& Adriana, 2019). Perusahaan perbankan yang terdaftar di BEI yang menunjukkan kinerja keuangan yang baik sehingga dapat mempengaruhi return sahamnya.

Proyeksi kinerja perusahaan dijadikan acuan bagi investor maupun analis fundamental dalam mengkaji saham perusahaan. Beberapa faktor yang menjadi sorotan adalah tingkat dividen tunai, tingkat rasio utang, rasio nilai buku/Price to book value (PBV), earnings per share (EPS), dan tingkat laba suatu perusahaan. Perusahaan yang menawarkan dividend payout ratio (DPR) yang lebih besar cenderung disukai investor karena bisa memberikan imbal hasil yang bagus. Dalam praktiknya, DPR berdampak pada harga saham. Selain itu, EPS juga dapat berpengaruh terhadap perubahan harga saham. EPS yang tinggi memotivasi para investor untuk membeli saham tersebut yang menyebabkan harga saham semakin tinggi. Tingkat PBV juga dapat memberikan pengaruh signifikan terhadap harga saham. Perusahaan yang memiliki tingkat rasio utang yang tinggi biasanya adalah perusahaan yang sedang berkembang. Perusahaan tersebut akan lebih aktif dalam mencari sumber pendanaan. Meskipun demikian, perusahaan seperti ini biasanya diminati banyak investor. Jika hasil analisis menunjukkan hasil yang baik, maka akan berdampak terhadap saham tersebut dengan memberikan imbal hasil tinggi (high return) karena membuat kapitalisasi pasar juga dapat meningkat.

Kinerja keuangan dalam penelitian ini diukur menggunakan rasio return on assets (ROA), debt to equity ratio (DER) dan non performing loan (NPL). Return on asset adalah salah satu rasio profitabilitas yang digunakan untuk mengukur kemampuan perusahaan perbankan dalam menghasilkan keuntungan dengan memanfaatkan aset yang dimilikinya. Return on asset yang tinggi merupakan suatu keberhasilan bank dalam memperoleh laba berdasarkan asetnya. Debt To Equity Ratio (DER) merupakan rasio solvabilitas yang mengukur kemampuan kinerja perusahaan perbankan dalam mengembalikan hutang jangka panjangnya dengan melihat perbandingan antara total hutang dengan total ekuitasnya (Kasmir, 2014). Kredit yang tidak tertagih (NPL atau Non Performing Loan) akan menuntut cadangan kerugian penurunan nilai (CKPN) untuk kredit yang tergolong kurang lancar, diragukan dan macet. Apabila NPL mencapai angka di atas $5 \%$, maka bank tersebut akan dibatasi dalam melakukan ekspansi kredit. NPL ini diperhitungkan dalam indikator penilaian kesehatan bank yang berasal dari faktor resiko kredit (Zaini et al., 2018).

Penerapan good corporate governance (GCG) diduga juga dapat mempengaruhi return saham. Saat ini setiap perusahaan harus menerapkan program good corporate governance sebagai bagian dari strategi bisnisnya, karena akan mempengaruhi penilaian investor terhadap perusahaan tersebut (Iqbal \& Zaib, 2017). Indonesia hanya memiliki lima perusahaan yang sudah masuk dalam kategori baik dalam penerapan GCG. Adapun, tiga di antaranya adalah perusahaan perbankan yaitu PT Bank Mandiri Tbk. (BMRI), PT CIMB Niaga Tbk. (CIMB), dan PT Bank Tabungan Negara Tbk. (BBTN). Peraturan mengenai GCG pada perusahaan merujuk kepada Peraturan Otoritas Jasa Keuangan (POJK) Nomor 55/PO]K.03/2016. Salah satu dari rangkaian aktivitas GCG setiap bank umum yang beroperasi di Indonesia yakni melakukan self assessment dengan menggunakan prinsip transparansi, akuntabilitas, responsibilitas, independensi, dan fairness setidaknya satu kali dalam setahun.

Price to book value dalam penelitian ini dijadikan variabel moderasi yaitu variabel yang memperkuat atau memperlemah hubungan antara variabel independen terhadap dependen karena adanya hubungan PBV terhadap return saham. Price to book value menunjukkan tingkat kemampuan perusahaan 
perbankan menciptakan nilai relatif terhadap jumlah modal yang diinvestasikan. Price to book value (PBV) yang tinggi mencerminkan harga saham yang tinggi dibandingkan nilai buku per lembar saham (Astuti, 2017). Semakin tinggi harga saham, semakin berhasil perusahaan perbankan menciptakan nilai bagi pemegang saham. Keberhasilan perusahaan perbankan menciptakan nilai tersebut tentunya memberikan harapan kepada pemegang saham berupa keuntungan yang lebih besar pula (Zaini et al., 2018).

Penelitian-penelitian mengenai return saham perlu dilakukan untuk memotivasi perusahaan perbankan dalam meningkatkan kinerja keuangan, penerapan good corporate governance dan nilai kapatilisasi pasar saham sehingga investor tertarik untuk berinvestasi pada perusahaan tersebut. Dengan adanya investasi dari investor maka perusahaan dapat menjalankan perusahaan dengan baik.

\subsection{Rumusan Masalah}

1. Apakah return on asset (ROA) terhadap return saham pada perusahaan perbankan di Bursa Efek Indonesia?

2. Apakah debt to equity ratio (DER) berpengaruh terhadap return saham pada perusahaan perbankan di Bursa Efek Indonesia?

3. Apakah non performing loan (NPL) berpengaruh terhadap return saham pada perusahaan perbankan di Bursa Efek Indonesia?

4. Apakah good corporate governance (GCG) berpengaruh terhadap return saham pada perusahaan perbankan di Bursa Efek Indonesia?

5. Apakah Price to book value (PBV) dapat memoderasi pengaruh return on asset (ROA) terhadap return saham pada perusahaan perbankan di Bursa Efek Indonesia?

6. Apakah Price to book value (PBV) dapat memoderasi pengaruh debt to equity ratio (DER) terhadap return saham pada perusahaan perbankan di Bursa Efek Indonesia?

7. Apakah Price to book value (PBV) dapat memoderasi pengaruh non performing loan (NPL) terhadap return saham pada perusahaan perbankan di Bursa Efek Indonesia?

8. Apakah Price to book value (PBV) dapat memoderasi pengaruh good corporate governance (GCG) terhadap return saham pada perusahaan perbankan di Bursa Efek Indonesia?

\subsection{Tujuan Penelitian}

1. Menganalisis pengaruh return on asset (ROA) terhadap return saham pada perusahaan perbankan di Bursa Efek Indonesia.

2. Menganalisis pengaruh debt to equity ratio (DER) terhadap return saham pada perusahaan perbankan di Bursa Efek Indonesia.

3. Menganalisis pengaruh non performing loan (NPL) terhadap return saham pada perusahaan perbankan di Bursa Efek Indonesia.

4. Menganalisis pengaruh good corporate governance (GCG) berpengaruh terhadap return saham pada perusahaan perbankan di Bursa Efek Indonesia.

5. Menganalisis Price to book value (PBV) dapat memoderasi pengaruh return on asset (ROA) terhadap return saham pada perusahaan perbankan di Bursa Efek Indonesia.

6. Menganalisis Price to book value (PBV) dapat memoderasi pengaruh debt to equity ratio (DER) terhadap return saham pada perusahaan perbankan di Bursa Efek Indonesia.

7. Menganalisis Price to book value (PBV) dapat memoderasi pengaruh non performing loan (NPL) terhadap return saham pada perusahaan perbankan di Bursa Efek Indonesia.

8. Menganalisis Price to book value (PBV) dapat memoderasi pengaruh good corporate governance (GCG) terhadap return saham pada perusahaan perbankan di Bursa Efek Indonesia.

\section{KAJIAN PUSTAKA DAN PERUMUSAN HIPOTESIS}

\subsection{Kajian Pustaka}

\section{a. Teori Stakeholder}

Perkembangan teori stakeholder diawali dengan berubahnya bentuk pendekatan perusahaan dalam melakukan aktifitas usaha. Gray et al (1996) menyatakan bahwa secara eksplisit, teori stakeholder mempertimbangkan dampak kebijakan pengungkapan perusahaan ketika ada perbedaan kelompok stakeholder dalam sebuah perusahaan.

\section{b. Teori Agensi (Agency Theory)}

Jensen \& Meckling (1976) menjelaskan bahwa agency theory merupakan teori yang menjelaskan adanya hubungan keagenan antara manajemen (agent) dengan pemilik perusahaan (principal), dimana wewenang dan tanggung jawab agent maupun principal telah diatur dalam kontrak kerja bersama untuk pengambilan keputusan atas nama principal.

\section{c. Teori Sinyal (Signaling Theory)}

Perspektif teori sinyal menekankan bahwa perusahaan dapat meningkatkan nilai perusahaan dengan memberikan sinyal kepada investor melalui pelaporan informasi terkait kinerja perusahaan sehingga dapat memberikan gambaran akan prospek usaha di masa datang. Semakin tinggi angka profitabilitas yang tercantum pada laporan keuangan, berarti semakin baik kinerja keuangan perusahaan, maka akan mencerminkan kekayaan investor yang semakin besar dan prospek perusahaan kedepan dinilai semakin menjanjikan

\section{d. Return Saham}

Setiap investasi baik jangka pendek maupun jangka panjang mempunyai tujuan utama untuk mendapatkan keuntungan yang disebut return, baik langsung maupun tidak langsung (Zaini et al., 2018). Return saham adalah tingkat keuntungan yang dinikmati oleh pemodal atas suatu investasi yang dilakukannya. 


\section{e. Return on Asset (ROA)}

ROA adalah rasio yang digunakan untuk mengukur keuntungan bersih yang diperoleh dari penggunaan aset (Kasmir, 2014). Dengan kata lain, semakin tinggi rasio ini maka semakin baik produktivitas asset dalam memperoleh keuntungan bersih. Hal ini selanjutnya akan meningkatkan daya tarik perusahaan kepada investor.

\section{f. Debt to Equity Ratio (DER)}

Debt to equity ratio adalah rasio utang yang diukur dari perbandingan utang dengan ekuitas (modal sendiri). Tingkat Debt to equity ratio (DER) yang aman biasanya kurang dari 50 persen. Semakin kecil debt to equity ratio semakin baik bagi perusahaan.

\section{g. $\quad$ Non Performing Loan (NPL)}

NPL yang tinggi akan memperbesar biaya, sehingga berpotensi terhadap kerugian bank. Kredit dalam hal ini adalah kredit yang diberikan kepada pihak ketiga tidak termasuk kredit kepada bank lain. Sesuai dengan aturan yang telah ditetapkan oleh Bank Indonesia, besarnya NPL yang baik adalah di bawah $5 \%$.

\section{h. Penerapan Good Corporate Governance}

Corporate governance didefinisikan oleh IICG (Indonesian institute of Corporate Governance) sebagai proses dan struktur yang diterapkan dalam menjalankan perusahaan, dengan tujuan utama meningkatkan nilai pemegang saham dalam jangka panjang, dengan tetap memperhatikan kepentingan stakeholders yang lain. Corporate governance juga mensyaratkan adanya struktur perangkat untuk mencapai tujuan dan pengawasan atas kinerja.

i. Price to book value

Price to book value (PBV) merupakan rasio pasar yang digunakan untuk mengukur kinerja harga pasar saham terhadap nilai bukunya (Kasmir, 2014). Book value per share digunakan untuk mengukur nilai shareholder equity atas setiap saham dan dasarnya nilai book value per share dihitung dengan membagi total shareholders equity dengan jumlah saham yang diterbitkan (outstanding shares).

\subsection{Kerangka Pemikiran}

a. Pengaruh Return on Asset Terhadap Return Saham

Return on asset merupakan rasio profitabilitas, dimana rasio profitabilitas adalah rasio yang mengukur kemampuan perusahaan dalam menghasilkan laba (Atidhira \& Yustina, 2017). Rasio profitabilitas dapat dihitung dengan membandingkan antara laba bersih dengan dengan jumlah aset. ROA menunjukan sejauh mana perusahaan mampu menghasilkan laba dari penggunaan aset untuk operasional perusahaan. Semakin tinggi rasio ini semakin baik, hal itu berarti semakin efektif penggunaan aset dalam menghasilkan laba (Qaisi et al., 2016). Jika perusahaan memiliki efektifitas yang baik dalam menghasilkan laba maka hal ini akan menarik para investor atau calon investor.

\section{b. Pengaruh Debt to Equity Ration Terhadap Return} Saham

Debt to equty Ratio menggambarkan seberapa jauh kemampuan perusahaan dalam membayar hutang jangka panjang dengan menggunakan modal sebagai jaminan (Kasmir, 2014). Semakin rendah angka rasio ini maka semakin baik. Penelitian Er \& Vuran (2012), Atidhira \& Yustina (2017) dan Qaisi et al (2016) menunjukkan bahwa debt to equty ratio berpengaruh positif dan signifikan pada return saham.

\section{c. Pengaruh Non Performing Loan Terhadap Return Saham}

Rasio aset produktif yang sering digunakan adalah non performing loan (NPL) dalam mengukur kemampuan manajemen bank dalam mengelola kredit bermasalah yang diberikan oleh bank (Perdana \& Adriana, 2019). Semakin tinggi rasio ini maka akan semakin buruk kualitas kredit bank yang menyebabkan jumlah kredit bermasalah semakin besar dan menyebabkan kerugian, sebaliknya jika semakin rendah NPL maka laba atau profitabilitas bank tersebut akan semakin meningkat (Mwaurah et al., 2017).

\section{d. Pengaruh Good corporate governance Terhadap} Return Saham

Good corporate governance (GCG) merupakan prinsip korporasi yang sehat yang perlu diterapkan dalam pengelolaan perusahaan yang dilaksanakan semata-mata demi menjaga kepentingan perusahaan dalam rangka mencapai maksud dan tujuan perusahaan (Nikodemus, 2017). Adanya GCG dapat meningkatkan nilai saham perusahaan. GCG dapat meyakinkan para investor di perusahaan bahwa mereka akan menerima return atas investasinya (Aloui \& Jarboui, 2018).

e. Pengaruh Price to book value (PBV) Sebagai Variabel Moderasi

Umumnya perusahaan-perusahaan yang dapat beroperasi dengan baik akan mempunyai rasio Price to book value (PBV) di atas 1, dimana hal ini menunjukkan nilai saham suatu perusahaan, dihargai diatas nilai bukunya (Astuti, 2017). Semakin tinggi rasio Price to book value (PBV) suatu perusahaan menunjukkan semakin tinggi pula penilaian investor terhadap perusahaan yang bersangkutan, relatif apabila dibandingkan dengan dana yang diinvestasikannya.

\subsection{Model Penelitian}

Adapun model dalam penelitian ini adalah sebagai berikut: 


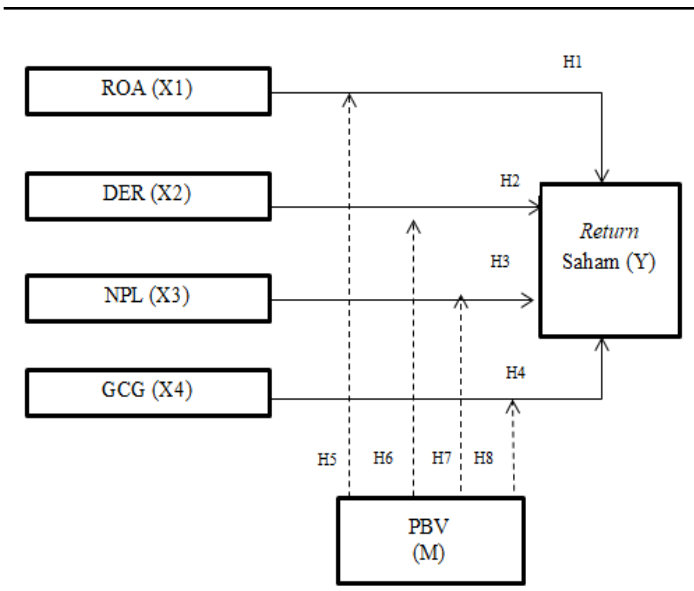

Sumber: Data diolah (2021)

Keterangan:

$$
\begin{aligned}
& =\text { Hubungan Secara Parsial } \\
& =\text { Hubungan Moderasi }
\end{aligned}
$$

\section{Gambar 1. Model Penelitian}

\subsection{Hipotesis}

$\mathrm{H}_{1}$ : Return on asset (ROA) berpengaruh terhadap return saham pada perusahaan perbankan di Bursa Efek Indonesia.

$\mathrm{H}_{2}$ : Debt to equity ratio (DER) berpengaruh terhadap return saham pada perusahaan perbankan di Bursa Efek Indonesia.

$\mathrm{H}_{3}$ : Non performing loan (NPL) berpengaruh terhadap return saham pada perusahaan perbankan di Bursa Efek Indonesia.

$\mathrm{H}_{4}$ : Good corporate governance (GCG) berpengaruh terhadap return saham pada perusahaan perbankan di Bursa Efek Indonesia.

$\mathrm{H}_{5}$ : Return on asset (ROA) berpengaruh terhadap return saham dimoderasi oleh Price to book value (PBV) pada perusahaan perbankan di Bursa Efek Indonesia.

$\mathrm{H}_{6}$ : Debt to equity ratio (DER) berpengaruh terhadap return saham dimoderasi oleh Price to book value (PBV) pada perusahaan perbankan di Bursa Efek Indonesia.

$\mathrm{H}_{7}$ : Non performing loan (NPL) berpengaruh terhadap return saham dimoderasi oleh Price to book value (PBV) pada perusahaan perbankan di Bursa Efek Indonesia.

$\mathrm{H}_{8}$ : Good corporate governance (GCG) berpengaruh terhadap return saham dimoderasi oleh Price to book value (PBV) pada perusahaan perbankan di Bursa Efek Indonesia.

\section{METODE PENELITIAN}

\subsection{Populasi dan Sampel}

Populasi dalam penelitian ini adalah seluruh perusahaan perbankan yang telah go public dan terdaftar di Bursa Efek Indonesia (BEI) periode 2015 sampai dengan 2019 yang diperoleh melalui website www.idx.co.id. Adapun jumlah populasi seluruh perusahaan perbankan yang terdaftar di BEI hingga tahun 2019 ada sebanyak 43 perusahaan. Sampel penelitian ini dipilih dengan menggunakan purposive sampling dengan kriteria sebagai berikut:

a. Perusahaan perbankan yang terdaftar di Bursa Efek Indonesia tahun 2015-2019

b. Perusahaan perbankan yang menerbitkan annual report dan melakuan self assesment penerapan GCG pada tahun 2015 sampai dengan tahun 2019

Sampel yang didapat setelah memilih berdasarkan kriteria diatas, maka 31 perusahaan dari 43 perusahaan yang memenuhi kriteria dan dijadikan sampel pada penelitian ini.

\subsection{Operasional Variabel}

\begin{tabular}{|c|c|c|}
\hline Variabel & Indikator & Skala \\
\hline $\begin{array}{l}\text { Return on } \\
\text { asset (X1) }\end{array}$ & $\mathrm{ROA}=\frac{\mathrm{EAT}}{\text { Total Aset }}$ & Rasio \\
\hline $\begin{array}{l}\text { Debt to equity } \\
\text { ratio (X2) }\end{array}$ & DER $=\frac{\text { total liabilitas }}{\text { total ekuitas }}$ & Rasio \\
\hline $\begin{array}{l}\text { Non } \\
\text { performing } \\
\text { loan (X3) }\end{array}$ & $=\frac{\text { NPL }}{\text { Total } \text { Kredit Bermasalah }}$ & Rasio \\
\hline $\begin{array}{l}\text { Good } \\
\text { Corporate } \\
\text { Governance } \\
\text { (X4) }\end{array}$ & $\begin{array}{c}\text { Nilai komposit } \\
\text { Peringkat penerapan } \\
\text { GCG }\end{array}$ & Rasio \\
\hline $\begin{array}{l}\text { Price to book } \\
\text { value }(\mathrm{M})\end{array}$ & $\mathrm{PBV}=\frac{\mathrm{PS}}{\mathrm{BVS}}$ & Rasio \\
\hline $\begin{array}{l}\text { Return Saham } \\
\text { (Y) }\end{array}$ & $R_{i t}=\frac{P_{i t}-P_{i t-1}}{P_{i t-1}}$ & Rasio \\
\hline
\end{tabular}

Tabel 1. Operasionalisasi variabel

Sumber: Data diolah (2021)

\subsection{Metode Analisis}

Metode analisis data yang digunakan dalam penelitian ini adalah metode regresi linear berganda dan Moderated Regression Analysis (MRA) atau uji interaksi dengan menggunakan program SPSS Versi 25 for windows. Metode ini dipilih karena dinilai paling relevan dengan penelitian dari pada metode-metode yang lainnya.

$\mathrm{Y}=\mathrm{a} 1+\mathrm{b} 1 \mathrm{X} 1+\mathrm{b} 5 \mathrm{X} 1 \mathrm{M}+\mathrm{e}$

$\mathrm{Y}=\mathrm{a} 2+\mathrm{b} 2 \mathrm{X} 2+\mathrm{b} 6 \mathrm{X} 2 \mathrm{M}+\mathrm{e}$

$\mathrm{Y}=\mathrm{a} 3+\mathrm{b} 3 \mathrm{X} 3+\mathrm{b} 7 \mathrm{X} 3 \mathrm{M}+\mathrm{e}$ 
$\mathrm{Y}=\mathrm{a} 4+\mathrm{b} 4 \mathrm{X} 4+\mathrm{b} 8 \mathrm{X} 4 \mathrm{M}+\mathrm{e}$

Sumber: Data diolah (2021)

Keterangan:

a $\quad=$ Konstanta

b1,.. b8 = Koefisien regresi variable X1, X2, X3, X4

$\mathrm{Y} \quad=$ Return Saham

$\mathrm{X} 1=\mathrm{ROA}$

$\mathrm{X} 2=\mathrm{DER}$

$\mathrm{X} 3=\mathrm{NPL}$

$\mathrm{X} 4 \quad=\mathrm{GCG}$

$\mathrm{X} 1 \mathrm{M}=$ Interaksi antara ROA dengan PBV

$\mathrm{X} 2 \mathrm{M}=$ Interaksi antara DER dengan PBV

$\mathrm{X} 3 \mathrm{M}=$ Interaksi antara NPL dengan PBV

$\mathrm{X} 4 \mathrm{M}=$ Interaksi antara GCG dengan PBV

$\mathrm{E} \quad=$ Error / variable yang tidak diteliti

\section{HASIL DAN PEMBAHASAN}

\subsection{Uji Asumsi Klasik}

a. Uji Normalitas

Uji normalitas data dilakukan dengan menggunakan kolmogorov-smirnov goodness of fit test. Uji ini dapat mengetahui distribusi nilai-nilai sampel teramati terdistribusi normal. Kriteria yang digunakan dengan dua arah (two tailed test), yaitu dengan membandingkan probabilitas ( $p$ value) yang diperoleh dengan tarif signifikansinya adalah 0,05 .

Tabel 2. Hasil Uji Normalitas

\begin{tabular}{|c|c|}
\hline & $\begin{array}{c}\text { Unstandardized } \\
\text { Residual }\end{array}$ \\
\hline $\begin{array}{c}\text { Asymp. Sig. } \\
\text { (2-tailed) }\end{array}$ &, $063^{\mathrm{c}}$ \\
\hline
\end{tabular}

Berdasarkan pada tabel uji Kolgomorov Smirnov di atas menunjukkan bahwa residual data berdistribusi normal dan model regresi telah memenuhi asumsi normalitas.

b. Uji Multikolinearitas

Tabel 3.Hasil Uji Multikolinearitas

\begin{tabular}{|c|c|c|c|}
\hline \multicolumn{4}{|c|}{ Coefficients $^{\mathrm{a}}$} \\
\hline & & \multicolumn{2}{|c|}{ Collinearity Statistics } \\
\hline \multicolumn{2}{|c|}{ Model } & Tolerance & VIF \\
\hline \multirow[t]{4}{*}{1} & ROA & ,784 & 1,276 \\
\hline & DER & ,892 & 1,122 \\
\hline & NPL &, 844 & 1,185 \\
\hline & GCG & ,803 & 1,245 \\
\hline & enden & RETURN & \\
\hline
\end{tabular}

Dari tabel di atas terlihat bahwa semua nilai VIF dari hasil regresi dibawah 10 dan nilai tolerance mendekati 1.Sehingga dapat disimpulkan tidak terjadi multikolinearitas.

c. Uji Autokorelasi

Tabel 4. Hasil Uji Autokorelasi

\begin{tabular}{|l|c|}
\hline \multicolumn{2}{|c|}{ Model Summary $^{\mathbf{b}}$} \\
\hline Model & Durbin-Watson \\
\hline 1 & $1,748^{\mathrm{a}}$ \\
\hline a. Predictors: (Constant), GCG, DER, NPL, ROA \\
\hline b. Dependent Variable: RETURN \\
Sumber: Hasil pengolahan data dengan SPSS
\end{tabular}

Berdasarkan hasil analisa yang dilakukan, maka diperoleh nilai Durbin Watson 1,748. Dengan demikian nilai Durbin Watson berada diantara nilai 1-2 yang berarti tidak ada autokorelasi.

d. Uji Heteroskedastisitas

Tabel 5.Hasil Uji Heteroskedastisitas

\begin{tabular}{|c|c|c|}
\hline \multicolumn{2}{|c|}{ Model } & Sig. \\
\hline \multirow{4}{*}{1} & (Constant) & 0,000 \\
\cline { 2 - 3 } 1 & $\mathrm{X} 1$ & 0,630 \\
\cline { 2 - 3 } & $\mathrm{X} 2$ & 0,163 \\
\cline { 2 - 3 } & $\mathrm{X} 3$ & 0,069 \\
\cline { 2 - 3 } & $\mathrm{X} 4$ & 0,288 \\
\hline
\end{tabular}

Sumber: Hasil pengolahan data dengan SPSS

Berdasarkan tabel di atas, menunjukkan bahwa pada model regresi tidak terjadi gejala heteroskedastisitas. Hal ini karena masing-masing variabel dari persamaan tersebut memiliki nilai probabilitas yang lebih besar dari nilai alpha (Sig. > 0.05) (Ghozali, 2016).

\subsection{Pengujian Hipotesis}

a. Persamaan MRA Variabel Return On Assets (ROA)

Tabel 6. Pengaruh Variabel Independen dan Moderasi Secara Simultan Terhadap Variabel Dependen

\begin{tabular}{|l|r|c|}
\hline \multicolumn{3}{|c|}{ Model Summary } \\
\hline Model & R Square & $\begin{array}{c}\text { Adjusted R } \\
\text { Square }\end{array}$ \\
\hline 1 &, 214 &, 203 \\
\hline \multicolumn{2}{|l|}{ a. Predictors: (Constant), X1M, ROA } \\
\hline
\end{tabular}

Besarnya angka Adjusted $R$ square $\left(R^{2}\right)$ adalah 0,203 . Angka tersebut mempunyai arti bahwa pengaruh 
Pengaruh Kinerja Keuangan dan Good Corporate Governance Terhadap Return Saham dengan Price Book Value Sebagai Variabel Moderasi Pada Perusahaan Perbankan di Bursa Efek Indonesia (Iin Tamarisa, Mukhzarudfa dan Wira)

variabel return on assets (ROA) serta variabel interaksi ROA dan PBV terhadap return saham secara simultan adalah 20,3\%. Untuk mengetahui kelayakan model regresi digambarkan angka-angka dari tabel ANOVA.

Tabel 7. ANOVA dengan nilai F dan Sig.

\begin{tabular}{|c|c|c|c|}
\hline \multicolumn{2}{|c|}{ Model } & F & Sig. \\
\hline 1 & Regression & 20,652 & $.000^{\mathrm{b}}$ \\
\hline
\end{tabular}

Hasil perhitungan diperoleh angka sig sebesar $0.000<0.05$ sehingga model regresi tersebut sudah layak dan benar. Kesimpulannya variabel ROA (X1) serta variabel interaksi ROA dan PBV (X1M) secara simultan mempengaruhi return saham. Besar pengaruhnya adalah $20,3 \%$ dan signifikan dengan signifikansi $0,000<\alpha=0,05$. Besar pengaruh variabel lain di luar model regresi tersebut dihitung dengan rumus: (1-r2) atau $(1-0,203)=0,797$ atau sebesar $79,7 \%$

Tabel 8. Hasil Analisis Regresi MRA Dengan Variabel Return On Assets

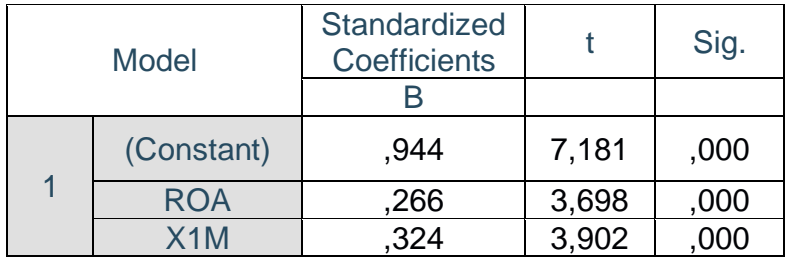

Sumber: Hasil pengolahan data dengan SPSS

Persamaan regresi yang diperoleh dari hasil uji di atas adalah:

$$
\mathrm{Y}=\mathbf{0 , 9 4 4}+\underset{\text { atau }}{\mathbf{0 , 2 6 6} \mathrm{X} 1}+\mathbf{0 , 3 2 4 \mathrm { X } _ { 1 } \mathrm { M }}
$$

Return Saham = 0,944 + 0,266 $($ ROA $)+0,324$ (Interaksi ROA \& PBV)

\section{Keterangan:}

1. Nilai konstanta 0,944 berarti bahwa proporsi variabel dalam penelitian ini diantaranya adalah return on assets (ROA) dan interaksi ROA dan PBV $\left(\mathrm{X}_{1} \mathrm{M}\right)$ dianggap konstan (bernilai nol) maka return saham pada perusahaan sampel adalah sebesar 0,944 .

2. Nilai koefisien 0,266 berarti bahwa jika variabel ROA ditingkatkan pada satu skala atau satu satuan, maka akan meningkatkan return saham pada angka 0,266.

3. Nilai koefisien 0,324 berarti bahwa jika variabel interaksi ROA dan PBV $\left(\mathrm{X}_{1} \mathrm{M}\right)$ ditingkatkan pada satu skala atau satu satuan, maka akan menaikkan return saham pada angka 0,324.

Tabel 9. Hasil Uji Statistik T

Persamaan MRA Variabel ROA

\begin{tabular}{|c|c|c|c|}
\hline \multicolumn{5}{|c|}{ Coefficients $^{\mathbf{a}}$} \\
\hline Model & $\begin{array}{c}\text { Unstandardized } \\
\text { Coefficients }\end{array}$ & $\mathrm{t}$ & Sig. \\
\hline
\end{tabular}

\begin{tabular}{|c|c|c|c|c|}
\hline \multicolumn{2}{|c|}{} & B & & \\
\hline \multirow{3}{*}{1} & (Constant) &, 944 & 7,181 &, 000 \\
\cline { 2 - 5 } & ROA &, 266 & 3,698 &, 000 \\
\cline { 2 - 5 } & X1M &, 324 & 3,902 &, 000 \\
\hline
\end{tabular}

Sumber: Hasil pengolahan data dengan SPSS

Berdasarkan tabel di atas menunjukkan bahwa return on assets (X1) memiliki tingkatan Sig. 0,000 lebih kecil dari taraf signifikansi 0,05 (5\%). Hal ini menunjukkan bahwa ROA terbukti berpengaruh signifikan terhadap return saham. Dengan demikian hipotesis pertama (H1) yang menyatakan bahwa ROA berpengaruh terhadap return saham dapat diterima.

Variabel interaksi ROA dan PBV $\left(\mathrm{X}_{1} \mathrm{M}\right)$ yang merupakan interaksi ROA dengan PBV memiliki tingkatan Sig. 0,000 lebih kecil dari taraf signifikansi $0,05(5 \%)$. Hal ini menunjukkan bahwa variabel interaksi ROA dan PBV $\left(\mathrm{X}_{1} \mathrm{M}\right)$ terbukti berpengaruh terhadap return saham. Berdasarkan uji t ROA (X1) dan interaksi ROA dan PBV $\left(\mathrm{X}_{1} \mathrm{M}\right)$ dapat disimpulkan bahwa variabel PBV memoderasi hubungan variabel ROA terhadap return saham perusahaan. Dengan demikian hipotesis kelima (H5) yang menyatakan bahwa ROA berpengaruh terhadap return saham dimoderasi PBV dapat diterima.

b. Persamaan MRA Variabel Debt to Equity Ratio (DER)

Tabel 10. Pengaruh Variabel Independen Dan Moderasi Secara Simultan Terhadap Variabel Dependen

\begin{tabular}{|c|c|c|}
\hline Model & R Square & $\begin{array}{c}\text { Adjusted R } \\
\text { Square }\end{array}$ \\
\hline 1 &, 107 &, 095 \\
\hline
\end{tabular}

Besarnya angka Adjusted $R$ square $\left(R^{2}\right)$ adalah 0,095. Angka tersebut mempunyai arti bahwa pengaruh variabel debt to equity ratio (DER) serta variabel interaksi DER dan PBV terhadap return saham secara simultan adalah 9,5\%. Untuk mengetahui kelayakan model regresi digambarkan angka-angka dari tabel ANOVA.

Tabel 11. ANOVA

\begin{tabular}{|l|l|l|l|}
\hline \multicolumn{2}{|l|}{ Model } & F & Sig. \\
\hline 1 & Regression & 9,109 &, $000^{\mathrm{b}}$ \\
\cline { 2 - 4 } & Residual & & \\
\cline { 2 - 4 } & Total & & \\
\hline
\end{tabular}

Sumber: Hasil pengolahan data dengan SPSS

Hasil perhitungan diperoleh angka sig sebesar $0.000<0.05$ sehingga model regresi tersebut sudah layak dan benar. Kesimpulannya variabel DER (X2) serta variabel interaksi DER dan PBV (X2M) secara simultan mempengaruhi return saham. Besar pengaruhnya adalah $9,5 \%$ dan signifikan dengan signifikansi $0,000<\alpha=0,05$. Besar pengaruh variabel lain di luar model regresi tersebut dihitung dengan 
rumus: $\left(1-\mathrm{r}_{2}\right)$ atau $(1-0,095)=0,905$ atau sebesar $90,5 \%$.

Tabel 12. Hasil Analisis Regresi MRA Dengan Variabel Debt to Equity Ratio

\begin{tabular}{|c|c|c|c|c|}
\hline \multicolumn{5}{|c|}{ Coefficients $^{\text {a }}$} \\
\hline \multirow{2}{*}{ Model } & $\begin{array}{c}\text { Unstandardized } \\
\text { Coefficients }\end{array}$ & $t$ & \multirow{2}{*}{ Sig. } \\
\cline { 2 - 5 } & B & & \\
\hline \multirow{2}{*}{1} & (Constant) & 2,046 & 8,992 &, 000 \\
\cline { 2 - 5 } & DER &,- 111 & $-3,077$ &, 002 \\
\cline { 2 - 5 } & X2M &, 082 & 3,623 &, 000 \\
\hline \multicolumn{4}{|c|}{ a. Dependent Variable: RETURN } \\
\hline
\end{tabular}

Sumber: Hasil pengolahan data dengan SPSS

Persamaan regresi yang diperoleh dari hasil uji di atas adalah:

$$
\begin{gathered}
\text { Y }=2,046-0,111 \text { X2 + 0,082 } \mathrm{X}_{2} \mathrm{M} \text { atau } \\
\text { Return Saham = 2,043 - 0,111 (DER) + 0,082 } \\
\text { (Interaksi DER \& PBV) }
\end{gathered}
$$

\section{Keterangan:}

1. Nilai konstanta 2,043 berarti bahwa proporsi variabel dalam penelitian ini diantaranya adalah debt to equity ratio (DER) serta interaksi DER dan PBV $\left(\mathrm{X}_{2} \mathrm{M}\right)$ dianggap konstan (bernilai nol) maka return saham pada perusahaan sampel adalah sebesar 2,043.

2. Nilai koefisien $-0,111$ berarti bahwa jika variabel DER ditingkatkan pada satu skala atau satu satuan, maka akan menurunkan return saham pada angka 0,111 .

3. Nilai koefisien 0,082 berarti bahwa jika variabel interaksi DER dan PBV $\left(\mathrm{X}_{2} \mathrm{M}\right)$ ditingkatkan pada satu skala atau satu satuan, maka akan menaikkan return saham pada angka 0,082 .

\begin{tabular}{|c|c|c|c|c|}
\hline & \multirow[t]{2}{*}{ Model } & $\begin{array}{l}\text { Unstandardized } \\
\text { Coefficients }\end{array}$ & \multirow[t]{2}{*}{$t$} & \multirow[t]{2}{*}{ Sig. } \\
\hline & & $\mathrm{B}$ & & \\
\hline \multirow{3}{*}{1} & (Constant) & 2,046 & 8,992 &, 000 \\
\hline & DER &,- 111 & $-3,077$ & ,002 \\
\hline & X2M & ,082 & 3,623 &, 000 \\
\hline
\end{tabular}

Tabel 13. Hasil Uji Statistik T Persamaan MRA Variabel DER

Berdasarkan tabel 13 di atas menunjukkan bahwa debt to equity ratio (X2) memiliki tingkatan Sig. 0,002 lebih kecil dari taraf signifikansi 0,05 (5\%). Hal ini menunjukkan bahwa DER terbukti berpengaruh signifikan terhadap return saham. Dengan demikian hipotesis pertama (H2) yang menyatakan bahwa DER berpengaruh terhadap return saham dapat diterima.

Variabel interaksi DER dan PBV $\left(\mathrm{X}_{2} \mathrm{M}\right)$ yang merupakan interaksi DER dengan PBV memiliki tingkatan Sig. 0,000 lebih kecil dari taraf signifikansi $0,05(5 \%)$. Hal ini menunjukkan bahwa variabel interaksi DER dan PBV $\left(\mathrm{X}_{2} \mathrm{M}\right)$ terbukti berpengaruh terhadap return saham. Berdasarkan uji t DER (X2) dan interaksi DER dan PBV $\left(\mathrm{X}_{2} \mathrm{M}\right)$ dapat disimpulkan bahwa variabel PBV memoderasi hubungan variabel DER terhadap return saham perusahaan. Dengan demikian hipotesis kelima (H6) yang menyatakan bahwa DER berpengaruh terhadap return saham dimoderasi PBV dapat diterima.

c. Persamaan MRA Variabel Non Performing Loan (NPL)

Tabel 14. Pengaruh Variabel Independen Dan Moderasi Secara Simultan Terhadap Variabel Dependen

\begin{tabular}{|c|c|c|}
\hline Model & R Square & $\begin{array}{c}\text { Adjusted R } \\
\text { Square }\end{array}$ \\
\hline 1 &, 112 &, 101 \\
\hline
\end{tabular}

Sumber: Hasil pengolahan data dengan SPSS

Besarnya angka Adjusted $R$ square $\left(R^{2}\right)$ adalah 0,101 . Angka tersebut mempunyai arti bahwa pengaruh variabel non performing loan (NPL) serta variabel interaksi NPL dan PBV terhadap return saham secara simultan adalah 10,1\%. Untuk mengetahui kelayakan model regresi digambarkan angka-angka dari tabel

\begin{tabular}{|c|c|c|c|}
\hline \multicolumn{2}{|c|}{ Model } & $\mathrm{F}$ & Sig. \\
\hline \multirow[t]{3}{*}{1} & Regression & 9,625 &, $000^{b}$ \\
\hline & Residual & & \\
\hline & Total & & \\
\hline
\end{tabular}
ANOVA.

Tabel 15. ANOVA

Hasil perhitungan diperoleh angka sig sebesar $0.000<0.05$ sehingga model regresi tersebut sudah layak dan benar. Kesimpulannya variabel NPL (X3) serta variabel interaksi NPL dan PBV (X3M) secara simultan mempengaruhi return saham. Besar pengaruhnya adalah $10,1 \%$ dan signifikan dengan signifikansi $0,000<\alpha=0,05$. Besar pengaruh variabel lain di luar model regresi tersebut dihitung dengan rumus: $\left(1-r_{2}\right)$ atau $(1-0,101)=0,899$ atau sebesar $89,9 \%$.

Tabel 16. Hasil Analisis Regresi MRA Dengan Variabel Non Performing Loan

\begin{tabular}{|c|c|c|c|c|}
\hline \multicolumn{5}{|c|}{ Coefficients $^{\mathbf{a}}$} \\
\hline \multirow{2}{*}{ Model } & $\begin{array}{c}\text { Unstandardized } \\
\text { Coefficients }\end{array}$ & \multirow{2}{*}{$\mathrm{t}$} & \multirow{2}{*}{ Sig. } \\
\cline { 2 - 5 } & $\mathrm{B}$ & & \\
\hline \multirow{3}{*}{1} & (Constant) & 1,653 & 12,517 &, 000 \\
\cline { 2 - 5 } & DER &,- 155 & $-2,926$ &, 004 \\
\cline { 2 - 4 } & $\mathrm{X} 3 \mathrm{M}$ &, 324 & 3,829 &, 000 \\
\hline \multicolumn{4}{|c|}{ a. Dependent Variable: RETURN } \\
\hline
\end{tabular}

Sumber: Hasil pengolahan data dengan SPSS

Persamaan regresi yang diperoleh dari hasil uji di atas adalah:

$$
\mathrm{Y}=\mathbf{1 , 6 5 3}-\mathbf{0 , 1 5 5} \mathrm{X3}+\mathbf{0 , 3 2 4} \mathrm{X}_{3} \mathrm{M} \text { atau }
$$




\section{Return Saham = 1,653 - 0,115 (NPL) + 0,324 (Interaksi NPL \& PBV)}

\section{Keterangan:}

1. Nilai konstanta 1,653 berarti bahwa proporsi variabel dalam penelitian ini diantaranya adalah non performing loan (NPL) dan interaksi NPL dan PBV $\left(\mathrm{X}_{3} \mathrm{M}\right)$ dianggap konstan (bernilai nol) maka return saham pada perusahaan sampel adalah sebesar 1,653 .

2. Nilai koefisien $-0,115$ berarti bahwa jika variabel NPL ditingkatkan pada satu skala atau satu satuan, maka akan menurunkan return saham pada angka 0,115 .

3. Nilai koefisien 0,324 berarti bahwa jika variabel interaksi NPL dan PBV $\left(\mathrm{X}_{3} \mathrm{M}\right)$ ditingkatkan pada satu skala atau satu satuan, maka akan menaikkan return saham pada angka 0,324 .

Tabel 17. Hasil Uji Statistik T Persamaan MRA Variabel NPL

\begin{tabular}{|c|c|c|c|c|}
\hline \multicolumn{5}{|c|}{ Coefficients $^{a}$} \\
\hline \multirow{2}{*}{\multicolumn{2}{|c|}{ Model }} & $\begin{array}{l}\text { Unstandardized } \\
\text { Coefficients }\end{array}$ & $\mathrm{t}$ & Sig. \\
\hline & & B & & \\
\hline \multirow{3}{*}{1} & (Constant) & 1,653 & 12,517 & ,000 \\
\hline & DER &,- 155 & $-2,926$ & ,004 \\
\hline & X3M & 324 & 3,829 & 000 \\
\hline \multicolumn{5}{|c|}{ a. Dependent Variable: RETURN } \\
\hline
\end{tabular}

Sumber: Hasil pengolahan data dengan SPSS

Berdasarkan tabel di atas menunjukkan bahwa non performing loan (X3) memiliki tingkatan Sig. 0,004 lebih kecil dari taraf signifikansi 0,05 (5\%). Hal ini menunjukkan bahwa NPL terbukti berpengaruh signifikan terhadap return saham. Dengan demikian hipotesis pertama (H3) yang menyatakan bahwa NPL berpengaruh terhadap return saham dapat diterima.

Variabel interaksi NPL dan PBV $\left(\mathrm{X}_{3} \mathrm{M}\right)$ yang merupakan interaksi NPL dengan PBV memiliki tingkatan Sig. 0,000 lebih kecil dari taraf signifikansi 0,05 (5\%). Hal ini menunjukkan bahwa variabel interaksi NPL dan PBV $\left(\mathrm{X}_{3} \mathrm{M}\right)$ terbukti berpengaruh terhadap return saham. Berdasarkan uji t NPL (X3) dan interaksi NPL dan PBV $\left(\mathrm{X}_{3} \mathrm{M}\right)$ dapat disimpulkan bahwa variabel PBV memoderasi hubungan variabel NPL terhadap return saham perusahaan. Dengan demikian hipotesis kelima (H7) yang menyatakan bahwa NPL berpengaruh terhadap return saham dimoderasi PBV dapat diterima.

d. Persamaan MRA Variabel Good Corporate Governance (GCG)

Tabel 18. Pengaruh Variabel Independen Dan Moderasi Secara Simultan Terhadap Variabel Dependen

\begin{tabular}{|c|c|c|}
\hline Model & R Square & $\begin{array}{c}\text { Adjusted R } \\
\text { Square }\end{array}$ \\
\hline
\end{tabular}

\begin{tabular}{|c|c|c|}
\hline 1 &, 170 &, 932522 \\
\hline
\end{tabular}

Besarnya angka Adjusted $R$ square $\left(R^{2}\right)$ adalah 0,159 . Angka tersebut mempunyai arti bahwa pengaruh variabel good corporate governance (GCG) serta variabel interaksi GCG dan PBV terhadap return saham secara simultan adalah $15,9 \%$. Untuk mengetahui kelayakan model regresi digambarkan angka-angka dari tabel ANOVA.

Tabel 19. ANOVA

\begin{tabular}{|l|l|c|c|}
\hline \multicolumn{2}{|l|}{ Model } & F & Sig. \\
\hline \multirow{3}{*}{1} & Regression & 15,585 &, $000^{\mathrm{b}}$ \\
\cline { 2 - 4 } & Residual & & \\
\cline { 2 - 4 } & Total & & \\
\hline \multicolumn{2}{|l|}{} & & \\
\hline
\end{tabular}

Hasil perhitungan diperoleh angka sig sebesar $0.000<0.05$ sehingga model regresi tersebut sudah layak dan benar. Kesimpulannya variabel GCG (X4) serta variabel interaksi GCG dan PBV (X4M) secara simultan mempengaruhi return saham. Besar pengaruhnya adalah $15,9 \%$ dan signifikan dengan signifikansi $0,000<\alpha=0,05$. Besar pengaruh variabel lain di luar model regresi tersebut dihitung dengan rumus: $\left(1-\mathrm{r}_{2}\right)$ atau $(1-0,159)=0,841$ atau sebesar $84,1 \%$.

Tabel 20. Hasil Analisis Regresi MRA Dengan Variabel $\boldsymbol{G C G}$

\begin{tabular}{|c|c|c|c|c|}
\hline \multicolumn{5}{|c|}{ Coefficients $^{\text {a }}$} \\
\hline \multirow{2}{*}{ Model } & $\begin{array}{c}\text { Unstandardized } \\
\text { Coefficients }\end{array}$ & \multirow{2}{*}{$\mathrm{t}$} & \multirow{2}{*}{ Sig. } \\
\cline { 2 - 5 } & $\mathrm{B}$ & & \\
\hline \multirow{3}{*}{1} & (Constant) & 2,641 & 6,719 &, 000 \\
\cline { 2 - 5 } & GCG &,- 683 & 3,424 &, 001 \\
\cline { 2 - 4 } & X4M &, 341 & 4,652 &, 000 \\
\hline \multicolumn{4}{|c|}{ a. Dependent Variable: RETURN } \\
\hline
\end{tabular}

Sumber: Hasil pengolahan data dengan SPSS

Persamaan regresi yang diperoleh dari hasil uji di atas adalah:

$$
\begin{gathered}
\text { Y= 2,641 + 0,683 X4 + 0,341 } \mathrm{X}_{4} \mathrm{M} \text { atau } \\
\text { Return Saham }=2,641+0,683(\mathrm{GCG})+0,341 \\
\text { (Interaksi GCG \& PBV) }
\end{gathered}
$$

\section{Keterangan:}

1. Nilai konstanta 2,641 berarti bahwa proporsi variabel dalam penelitian ini diantaranya adalah good corporate governance (GCG) dan interaksi GCG dan PBV $\left(\mathrm{X}_{4} \mathrm{M}\right)$ dianggap konstan (bernilai nol) maka return saham pada perusahaan sampel adalah sebesar 2,641.

2. Nilai koefisien 0,683 berarti bahwa jika variabel GCG ditingkatkan pada satu skala atau satu satuan, maka akan menaikkan return saham pada angka 0,683 .

3. Nilai koefisien 0,341 berarti bahwa jika variabel interaksi GCG dan PBV $\left(\mathrm{X}_{4} \mathrm{M}\right)$ ditingkatkan pada 
satu skala atau satu satuan, maka akan menaikkan return saham pada angka 0,341 .

Tabel 21. Hasil Uji Statistik T Persamaan MRA Variabel GCG

\begin{tabular}{|c|c|c|c|c|}
\hline \multicolumn{5}{|c|}{ Coefficients $^{\mathbf{a}}$} \\
\hline \multirow{2}{*}{ Model } & $\begin{array}{c}\text { Unstandardized } \\
\text { Coefficients }\end{array}$ & \multirow{2}{*}{$\mathrm{t}$} & \multirow{2}{*}{ Sig. } \\
\cline { 2 - 5 } \multicolumn{2}{|c|}{} & B & & \\
\hline \multirow{3}{*}{1} & (Constant) & 2,641 & 6,719 &, 000 \\
\cline { 2 - 5 } & DER &, 683 & 3,424 &, 001 \\
\cline { 2 - 5 } & X4M &, 341 & 4,652 &, 000 \\
\hline
\end{tabular}

a. Dependent Variable: RETURN

Sumber: Hasil pengolahan data dengan SPSS

Berdasarkan tabel di atas menunjukkan bahwa good corporate governance (X4) memiliki tingkatan Sig. 0,001 lebih kecil dari taraf signifikansi 0,05 (5\%). Hal ini menunjukkan bahwa GCG terbukti berpengaruh signifikan terhadap return saham. Dengan demikian hipotesis pertama (H4) yang menyatakan bahwa GCG berpengaruh terhadap return saham dapat diterima.

Variabel interaksi GCG dan PBV $\left(\mathrm{X}_{4} \mathrm{M}\right)$ yang merupakan interaksi GCG dengan PBV memiliki tingkatan Sig. 0,000 lebih kecil dari taraf signifikansi $0,05(5 \%)$. Hal ini menunjukkan bahwa variabel interaksi GCG dan PBV $\left(\mathrm{X}_{4} \mathrm{M}\right)$ terbukti berpengaruh terhadap return saham. Berdasarkan uji t GCG (X4) dan interaksi GCG dan PBV $\left(\mathrm{X}_{4} \mathrm{M}\right)$ dapat disimpulkan bahwa variabel PBV memoderasi hubungan variabel GCG terhadap return saham perusahaan. Dengan demikian hipotesis kelima (H8) yang menyatakan bahwa GCG berpengaruh terhadap return saham dimoderasi PBV dapat diterima. Dengan kata lain, variabel PBV merupakan variabel moderasi.

\subsection{Pembahasan}

1. Hasil penelitian return on assets (ROA) menunjukkan pengaruh terhadap return saham dengan nilai signifikansi 0,002 atau di bawah $5 \%$. Ini berarti bahwa semakin meningkatnya tingkat return on assets (ROA) akan mempengaruhi return saham maka hipotesis pertama pada penelitian ini diterima. Hasil penelitian ini memberikan pemahaman empirik bahwa jika ROA naik, maka return saham juga naik, kondisi ini menggambarkan bahwa perolehan ROA yang meningkat akan berdampak pada kenaikan return saham. ROA yang tinggi akan mencerminkan kemampuan perusahaan dalam menghasilkan keuntungan yang tinggi bagi pemegang saham.

2. Hasil penelitian debt to equity ratio (DER) menunjukkan pengaruh terhadap return saham dengan nilai signifikansi 0,002 atau di bawah 5\% namun berpengaruh negatif. Ini berarti bahwa semakin meningkatnya tingkat debt to equity ratio (DER) akan mempengaruhi return saham maka hipotesis kedua pada penelitian ini diterima. Hasil penelitian ini memberikan pemahaman empirik bahwa jika DER naik, maka return saham akan menurun, kondisi ini menggambarkan bahwa perolehan DER yang meningkat akan berdampak pada menurunnya return saham. Dan sebaliknya jika rasio DER menurun maka return saham akan meningkat.

3. Hasil penelitian non performing loan (NPL) menunjukkan pengaruh terhadap return saham dengan nilai signifikansi 0,004 atau di bawah 5\% namun berpengaruh negatif. Ini berarti bahwa semakin meningkatnya tingkat non performing loan (NPL) akan mempengaruhi return saham maka hipotesis ketiga pada penelitian ini diterima. Hasil penelitian ini memberikan pemahaman empirik bahwa jika NPL naik, maka return saham akan menurun, kondisi ini menggambarkan bahwa perolehan NPL yang meningkat akan berdampak pada menurunnya return saham. Dan sebaliknya jika nilai NPL menurun maka return saham akan meningkat.

4. Hasil penelitian good corporate governance (GCG) menunjukkan pengaruh terhadap return saham dengan nilai signifikansi 0,001 atau di bawah 5\%. Ini berarti bahwa semakin tinggi predikat tingkat GCG akan mempengaruhi return saham maka hipotesis keempat pada penelitian ini diterima. Hasil penelitian ini memberikan pemahaman empirik bahwa semakin baik tingkat GCG, maka return saham juga naik, kondisi ini menggambarkan bahwa semakin baik tingkat GCG akan berdampak pada kenaikan return saham. Predikat GCG yang tinggi akan mencerminkan kemampuan perusahaan dalam mengelola perusahaan.

5. Hasil penelitian analisis regresi MRA menunjukkan bahwa variabel interaksi ROA dan PBV memiliki tingkatan Sig. 0,000 lebih kecil dari taraf signifikansi 0,05 (5\%). Hal ini menunjukkan bahwa variabel interaksi return on assets dan PBV terbukti berpengaruh terhadap return saham. Variabel PBV memoderasi hubungan variabel ROA terhadap return saham. Dengan demikian hipotesis kelima (H5) yang menyatakan bahwa return on assets berpengaruh terhadap return saham dimoderasi PBV dapat diterima. Dengan kata lain, variabel PBV merupakan variabel moderasi.

6. Hasil penelitian analisis regresi MRA menunjukkan bahwa variabel interaksi DER dan PBV memiliki tingkatan Sig. 0,000 lebih kecil dari taraf signifikansi 0,05 (5\%). Hal ini menunjukkan bahwa variabel interaksi debt to equity ratio dan PBV terbukti berpengaruh terhadap return saham. Variabel PBV memoderasi hubungan variabel DER terhadap return saham. Dengan demikian hipotesis keenam (H6) yang menyatakan bahwa debt to equity ratio berpengaruh terhadap return saham dimoderasi PBV dapat diterima. Dengan kata lain, variabel PBV merupakan variabel moderasi. 
7. Hasil penelitian analisis regresi MRA menunjukkan bahwa variabel interaksi NPL dan PBV memiliki tingkatan Sig. 0,000 lebih kecil dari taraf signifikansi $0,05(5 \%)$. Hal ini menunjukkan bahwa variabel interaksi non performng loan dan PBV terbukti berpengaruh terhadap return saham. Variabel PBV memoderasi hubungan variabel NPL terhadap return saham. Dengan demikian hipotesis ketujuh (H7) yang menyatakan bahwa non performing loan berpengaruh terhadap return saham dimoderasi PBV dapat diterima. Dengan kata lain, variabel PBV merupakan variabel moderasi.

8. Hasil penelitian analisis regresi MRA menunjukkan bahwa variabel interaksi GCG dan PBV memiliki tingkatan Sig. 0,000 lebih kecil dari taraf signifikansi 0,05 (5\%). Hal ini menunjukkan bahwa variabel interaksi good corporate governance dan PBV terbukti berpengaruh terhadap return saham. Variabel PBV memoderasi hubungan variabel GCG terhadap return saham. Dengan demikian hipotesis kedelapan (H8) yang menyatakan bahwa good corporate governance berpengaruh terhadap return saham dimoderasi PBV dapat diterima. Dengan kata lain, variabel PBV merupakan variabel moderasi.

\section{SIMPULAN DAN SARAN}

\subsection{Simpulan}

1. Return on assets (ROA) berpengaruh signifikan terhadap return saham, hal ini mengindikasikan bahwa semakin tinggi rasio ROA perusahaan perbankan yang terdaftar di Bursa Efek Indonesia yang menjadi sampel pada penelitian ini maka return saham juga akan meningkat. Hal ini sesuai dengan teori sinyal bahwa semakin tinggi rasio ROA perusahaan maka akan menjadi sinyal yang baik bahwa return saham akan meningkat.

2. Debt to equiy ratio (DER) berpengaruh signifikan terhadap return saham, hal ini mengindikasikan bahwa semakin rendah rasio DER perusahaan perbankan yang terdaftar di Bursa Efek Indonesia yang menjadi sampel pada penelitian ini maka return saham akan meningkat. Hal ini sesuai dengan teori sinyal bahwa semakin rendah atau tinggi rasio DER perusahaan maka akan mempengaruhi return saham karena dapat menjadi sinyal yang diterima oleh investor.

3. Non performing loan (NPL) berpengaruh signifikan terhadap return saham, hal ini mengindikasikan bahwa semakin rendah rasio NPL perusahaan perbankan yang terdaftar di Bursa Efek Indonesia yang menjadi sampel pada penelitian ini maka return saham akan meningkat. Hal ini sesuai dengan teori sinyal bahwa semakin rendah atau tinggi rasio NPL perusahaan maka akan mempengaruhi return saham karena dapat menjadi sinyal yang diterima oleh investor.
4. Good corporate governance (GCG) berpengaruh signifikan terhadap return saham, hal ini mengindikasikan bahwa semakin baik predikat GCG perusahaan perbankan yang terdaftar di Bursa Efek Indonesia yang menjadi sampel pada penelitian ini maka return saham juga akan meningkat. Hal ini sesuai dengan teori sinyal bahwa semakin baik predikat GCG perusahaan maka akan menjadi sinyal yang baik bahwa return saham akan meningkat.

5. Return on assets (ROA) berpengaruh signifikan terhadap return saham dimoderasi oleh price book value (PBV). PBV merupakan variabel moderasi. PBV dapat memperkuat pengaruh ROA terhadap return saham pada perusahaan perbankan yang terdaftar di Bursa Efek Indonesia periode 20152019 yang menjadi sampel pada penelitian ini.

6. Debt to equity ratio (DER) berpengaruh signifikan terhadap return saham dimoderasi oleh price book value (PBV). PBV merupakan variabel moderasi. PBV dapat memperkuat pengaruh DER terhadap return saham pada perusahaan perbankan yang terdaftar di Bursa Efek Indonesia periode 20152019 yang menjadi sampel pada penelitian ini.

7. Non performing loan (NPL) berpengaruh signifikan terhadap return saham dimoderasi oleh price book value (PBV). PBV merupakan variabel moderasi. PBV dapat memperkuat pengaruh NPL terhadap return saham pada perusahaan perbankan yang terdaftar di Bursa Efek Indonesia periode 2015-2019 yang menjadi sampel pada penelitian ini.

8. Good corporate governance (GCG) berpengaruh signifikan terhadap return saham dimoderasi oleh price book value (PBV). PBV merupakan variabel moderasi. PBV dapat memperkuat pengaruh GCG terhadap return saham pada perusahaan perbankan yang terdaftar di Bursa Efek Indonesia periode 2015-2019 yang menjadi sampel pada penelitian ini.

\subsection{Saran}

Berdasarkan hasil analisis penelitian yang dilakukan penulis dan atas keterbatasan yang dimiliki oleh penulis, maka dapat diberikan saran sebagai berikut:

1. Bagi peneliti selanjutnya

a. Bagi peneliti diharapkan dapat menggunakan alat ukur lain atau proxy lain untuk melihat faktor yang mempengaruhi return saham. Penelitian selanjutnya dapat menggunakan pengukuran lainnya, seperti earning per share, dsb. Selain itu, penelitian ini juga menggunakan rasio ROA, DER, NPL dan GCG, penelitian selanjutnya dapat menambahkan indikator lain seperti rasio likuiditas dan lainnya.

b. Penelitian ini hasil pengujian variabel moderasi dengan uji MRA (Moderated 
Regression Analyze) menunjukan hasil bahwa variabel price book value merupakan moderator dalam pengaruh ROA, DER, NPL dan GCG terhadap return saham, untuk penelitian selanjutnya agar bisa menggunakan variabel moderasi lainnya atau penggunaan variabel sebagai variabel mediasi untuk mengetahui pengaruhnya terhadap nilai perusahaan seperti pertumbuhan laba dan ukuran perusahaan.

c. Bagi peneliti dapat memperluas ruang lingkup penelitian, tidak hanya pada perusahaan perbankan yang terdaftar di bursa efek Indonesia saja. Dan dapat mengembangkan hasil penelitian dengan menambahkan sektor industri lainnya sebagai sampel serta memperpanjang periode penelitian agar memperoleh hasil yang lebih akurat dan memiliki cakupan yang lebih luas.

2. Bagi perusahaan

Perusahaan diharapkan dapat meningkatkan return saham sehingga dapat menarik investor untuk berinvestasi pada perusahaan mereka, serta dalam pengambilan keputusan dan pengambilan kebijakan dalam meningkatkan harga saham juga perlu memperhatikan price book value agar perusahaan memiliki fleksibilitas keuangan dalam mencapai return saham yang baik bagi pihak internal maupun eksternal. Manajemen harus dapat meningkatkan kinerjanya untuk menghasilkan profit guna meningkatkan return saham. Oleh karena itu, perusahaan perbankan dapat menjadikan hasil penelitian ini sebagai bahan pertimbangan dalam rangka peningkatan return saham.

\section{DAFTAR REFERENSI}

Aloui, M., \& Jarboui, A. (2018). The effects of corporate governance on the stock return volatility : During the financial crisis International Journal of Law and Management Article information: International Journal of Law and Managemen. https://doi.org/10.1108/IJLMA-012017-0010.

Astuti. (2017). Analisis Faktor-Faktor yang Mempengaruhi Return Saham dengan Likuiditas Sebagai Variabel Moderating pada Perusahaan yang Terdaftar dalam Indeks LQ45 di Bursa Efek Indonesia. Tesis Universitas Sumatera Utara.

Atidhira, A. T., \& Yustina, A. I. (2017). The Influence of Return on Asset, Debt to Equity Ratio, Earnings per Share, and Company Size on Share Return in Property and Real Estate Companies. JAAF (Journal of Applied Accounting and Finance), 1(2), 128-146. http://ejournal.president.ac.id/presunivojs/index.php/JAA F/article/download/363/207.
Brigham, Eugene F \& Houston, Joel F. (2017). Dasardasar Manajemen Keuangan. Jakarta: Salemba Empat.

Er, Ş., \& Vuran, B. (2012). Factors Affecting Stock Returns of Firms Quoted in ISE Market: A Dynamic Panel Data Approach. International Journal of Business and Social Research (IJBSR), 2(1), 108-121. https://doi.org/10.18533/ijbsr.v2i1.209.

Ghozali, Imam \& Chariri, Anis. (2016). Teori Akuntansi. Semarang: Badan Penerbit Universitas Diponegoro.

Ghozali, Iman. (2016). Aplikasi Analisis Multivariete dengan Program SPSS 25. Semarang: Badan Penerbit Universitas Diponegoro.

Gray, R., Kouhy, R., \& Lavers, S, (1996). Corporate social and environmental reporting . Accounting, Auditing \& Accountability Journal. .

Husnan, Suad. (2015). Dasar-dasar Teori Portofolio dan Analisis Sekuritas. Edisi Ketiga. Jakarta: BPFE.

Iqbal, J., \& Zaib, J. (2017). Corporate Governance , Intellectual Capital and Financial Performance of Banks listed in Pakistan Stock Exchange Corporate Governance, Intellectual Capital and Financial Performance of Banks listed in Pakistan Stock Exchange. Pakistan Administrative Review, 1(3), 175-196.

Jensen, C., \& Meckling, H. (1976). Theory of The Firm: Managerial Behavior, Agency Costs And Ownership Structure I Introduction and summary In this paper WC draw on recent progress in the theory of ( 1 ) property rights, firm. In addition to tying together elements of the theory of e. 3, 305360 .

Jogiyanto, Hartono. (2015). Teori Portofolio dan Analisis Investasi. Yogyakarta: BPFE.

Kasmir. (2014). Analisis Laporan Keuangan. Jakarta: Raja Grafindo Persada.

Mohammed, Garba Tahir. (2017). Impact Of Firm Characteristics On Firm Value Of Listed Healthcare Firms In Nigeria. Dissertation. Zaria: Ahmadu Bello University.

Mwaurah, Isaac., Muturi, Dr. Willy dan Waititu, Dr. Anthony. (2017). The Influence of Financial Risk on Stock Returns. International Journal of Scientific and Research Publications. Vol. 7, No. 5. ISSN: 2250-3153.

Nikodemus, J. (2017). Pengaruh Kinerja Keuangan dan Mekanisme Good Corporate Governance (GCG) Terhadap Return Saham dengan Nilai Pasar Sebagai Variabel Moderating Pada Perusahaan Perbankan yang Terdaftar di BEI. Tesis. Universitas Sumatera Utara. 
Otoritas Jasa Keuangan. (2019). Statistik Perbankan Indonesia (SPI) Vol 16, No. 17, Desember 2019.

Perdana, M. K \& Adriana, C. H. (2019). Factors Influencing the Stock Price of Banking Companies in the Indonesia Stock Exchange. Journal of Accounting and Strategic Finance, 1(01), 57-68. https://doi.org/10.33005/jasf.v1i01.26

Qaisi, F. Al, Al-qudah, M., \& Tahtamouni, D. A. (2016). Factors Affecting the Market Stock Price The Case of the Insurance Companies Listed in Amman Stock Exchange. International Journal of Business and Social Science, 7(10), 81-90. https://doi.org/ISSN: 2219-1933.

Santoso, Wimboh. (2020). Kondisi Bank 2019: Kredit Tumbuh Cuma 6,08\%, NIM Turun 4,19\% melalui https://www.cnbcindonesia.com/market/202001 16103000-17130397/kondisi-bank-2019-kredittumbuh-cuma-608-nim-turun-491 diakses pada tanggal 20 Februari 2020.

Sayedy, B., \& Ghazali, M. Z. (2017). The Impact of Microeconomic Variables on Stock Return by Moderating of Money Supply. Asian Social Science, $13(12), 191$. https://doi.org/10.5539/ass.v13n12p191.

Zaini, V. I., Sadalia, I., \& Fachrudin, K. A. (2018). The Effect Of External And Internal Factors On Stock Return With Price To Book Value As Moderation Variables In Banking Companies In Indonesia Stock Exchange. International Journal of Scientific and Technology Research, 7(9), 77-82. 